口特＼cjkstart集〈聴覚と音声言語〉

\title{
中・高度聴覚障害児の音声障害と幼児期の指導との関係
}

\author{
廣田 栄子 田中 美郷
}

要 約：普通小学校に在籍する中・高度感音性聴覚障害児 112 例を対象として, 自由発話の 音声, 発語明瞭度, 語音明瞭度について検討し, 症例の聴力, 幼児期の教育環境, 言語メディ アの要因について分折した。その結果，1）難聴が高度になると音声の障害の程度が重度にな り，障害の種類が増加した。2 ）幼児期にろう学校を経た症例では，正常児統合例と比べて語 音弁別能, 発語明瞭度の障害が顕著であり, 発話速度が低下した．３）幼児期の言語メディア に手指法を用いた症例では，聴覚口話法例と比べて韻律的障害が顕著であった。発語明瞭度に ついては, 手指法を用いた例では聴覚口話法を用いた例より, 障害が軽度であった。 4) 教育 要因の差異が聴覚障害児の音声障害の程度に及ぼす影響は, 聴力レベルの差異がもたらす影響 より顕著でなかった。 5 ) 言語力については, 聴力の要因や, 各種教育要因による差異を認め なかった.

索引用語：聴覚障害, 音声障害, 聴力レベル, 言語メディア, 統合教育

\section{The Effect of Preschool Educational Settings and Different Language Media on Voice Problems of Children with Moderate and Severe Hearing Loss}

\section{Eiko Hirota and Yoshisato Tanaka}

\begin{abstract}
As factors affecting the voice problems of hearing impaired children, the level of hearing loss, preschool educational setting and different language media have been considered. One hundred and twelve children with moderate and severe hearing impairments who attended regular primary schools were selected for the present investigation to study acoustic analysis, articulation and speech discrimination. Consequently, 1) severe hearing-impaired children were found to be accompanied by a number of impairments according to the degree of voice problems. 2) Articulation and speech discrimination of hearing-impaired children who attended special preschools for the deaf was worse than that of those who attended regular kindergartens, and rate of utterances was low. 3 ) Children who were applied manual communication as language media showed remarkable problems on suprasegmental aspects (pitch, intonation, variation of intensity and rate of utterance) than those who were educated by auditory-oral method. As for speech intelligibility, children taught by manual communication showed slighter problems than those by auditory-oral method. 4 ) Different educational settings affecting the voice problems of hearing-impaired children was smaller than different hearing level. 5 ) Language ability was not affected by such factors like hearing loss or different educational setting.
\end{abstract}


Key words : hearing-impaired children, voice problems, language media, hearing level, educational setting

\section{I 、はじめに}

近年の乳幼児の音声の研究では, 生後 $6 \sim 7$ カ月に は, 母国語の韻律に類似した発声パターンを認め ${ }^{11}$, 生 後 $4 \sim 5$ 年間に母国語の基本的な音韻を獲得する ${ }^{2)}$ 報告されている．先天性聴覚障害児では，このような 出生時からの聴覚系による音声情報が制限され, 音声 言語の獲得には教育的援助が必要であることは周知の とおりである。

近年の他覚的聴力検查の進歩は, 早ければ出生後 2 $\sim 3$ 力月に難聴を診断し ${ }^{3)}$, 生後 6 力月には補聴器装 用を開始し, 乳幼児からの聴覚補償を技術的に可能に しだ)。そこで, 聴覚障害児の音声については, 近年, 質的な向上が認められ, 新しい評価の尺度が要請され ている. 同時に, 乳幼児期よりの教育的援助によって 聴覚障害児の音声障害の程度がどのように左右される かについての現時点での資料が必要とされている.

欧米では, 聴覚障害児の音声障害について組織的に 教育要因を分折した研究 ${ }^{5 \sim 7}$ があるものの, 本邦では報 告が少なく ${ }^{8 \sim 11)}$, 資料として十分とはいえない. 言語の ちがいを配慮し, わが国の教育事情を背景として, 各 種の教育要因を検討する必要性は, 諸家の等しく強調 するところである。

さらに, 聴覚障害児の音声障害についての従来の研

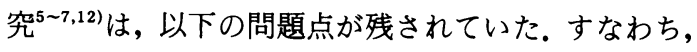
従来の研究では, 高度聴覚障害児を一括して対象とし たために，1）難聴の程度別の障害の種類や，2）難 聴が重くなるにつれ, 複数の障害が重複して惹起する 経過が明らかではなく，３）指導方法と音声障害との 関連性の検討に, 難聴の程度の影響が十分検討されて ない.また，4）幼児期の言語教育要因（教育環境お よび, 言語メディア)の影響が就学後に残る可能性や, 5 ) 言語教育要因相互の比較検討が乏しいという問題 点があげられる.

著者らは以前に，上記の 1）〜 4) について方法的 に改善し, 聴覚障害児の音声言語の障害について, 障 害の程度 ${ }^{13)}$, 手指言語のメディアの併用 ${ }^{11}$, 正常児集団 との交流の影響 ${ }^{10)}$ を検討した。 そこで, 本研究では, 中 高度感性聴覚障害児の音声障害について, 残された問 題である 5 )教育要因間の影響の差異について検討し, 難聴の程度との関係を再検討した。

\section{II. 対象と方法}

東京都および近県の普通小学校に 1 年以上在籍する 感音性聴覚障害児 112 例を対象とした。表 1 に, 被検 児の平均聴力レベルと, 幼児期の教育環境, 言語メデ イアなどの教育的要因別の症例数を示した。

幼児期の教育環境については, 聴力 $80 \mathrm{~dB}$ 以上の症 例 84 例のうち, 万う学校幼稚部で指導を受けた症例は 39 例であり, 残りの 45 例と聴力 $80 \mathrm{~dB}$ 未満の 28 例 は, 幼児期に病院や通園施設で指導を受け, 普通幼稚 園や保育園に通園した。

幼児期の言語メディアとしては, ろう学校幼稚部に 通学した 39 例のうち, 聴覚での受信と音声での発信に 手指法を併用した症例は 14 例であった。そのうち, 子 音部のみを手指記号で示し, 口型で示す 5 母音と総合 して語音を受信させるキュードスピーチは， 7 例で用 いられた. 日本語の 101 音節に対応した手指記号で語 音を示す指文字は，7例で用いられた。 ろう学校幼稚 部に通学した残りの 25 例と, 病院や通園施設で指導を 受けた 73 例には, 聴覚口話法が用いられた。聴覚口話 法では, 聴覚と読話, 音声が言語メディアとして用い られた.なお, 言語メディアの要因を検討する際には, ろう学校幼稚部に通学した症例で結果を比較した。

以上の被検児を対象として, 連続的発話サンプル ( 1 分間) について, 発話のピッチ, 抑揚 (ピッチの変動) 音圧の変動, 速度について音響的に分析し, 音声障害 の評価を行った. 被検児の発話のピッチは, 基本周波 数の平均值を用い, 抑揚は基本周波数の 1 標準偏差, 音声の強さの変動には音声強度の 1 標準偏差を測定し て算出した (visi-pitch, Kay.社, 6097 使用)。抑揚に

表 1 被検児の平均聴カレベルと症例数 幼児期の教育環境

\begin{tabular}{ccc}
\hline & \multicolumn{3}{c}{ 幼児期の教育環境 } \\
聴力程度 & ろう学校幼稚部 & 正常児と統合 \\
\hline $50 \sim 69 \mathrm{~dB}$ & 0 & 14 \\
$70 \sim 79 \mathrm{~dB}$ & 0 & 14 \\
$80 \sim 89 \mathrm{~dB}$ & $11(4)$ & 17 \\
$90 \sim 99 \mathrm{~dB}$ & $14(5)$ & 14 \\
$100 \mathrm{~dB}$ 以上 & $14(5)$ & 14 \\
\hline 計 & $39(14)$ & 73 \\
\hline ( ) 内は手指法併用例の症例数を示し, それ以外 \\
は, 聴覚口話法例の症例数を示す.
\end{tabular}


ついては, 症例ごとに基本周波数の 1 標準偏差を基本 周波数で除して規準化し, 音声の強さの変動について は, 症例ごとに音声強度の 1 標準偏差を音声強度で除 して規準化した。発話の速さには，1 拍あたりの持続 時間を測定した。

被検児に, 100 音節を発話させて録音し,テープレコ ーダで再生して著者らが評価し, 発語明瞭度を調べた。

スピーカ前に被検児を着席させ, 補聴器装用下に 57 式または $57 \mathrm{~S}$ 式語音明瞭度検査を行った。検査語音の 提示音圧については, 較正用純音が被検児の補聴器の

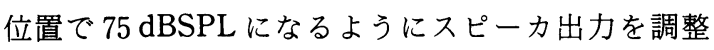
した。検査の教示用音声が被検児の聞き取りやすいレ ベルになるように, 補聴器の音響利得を調整させて検 査を行った。

音声および聴取能の障害の群間の差については，u 検定を用いて有意差を検定した $(\mathrm{p}<0.01$ : 図中星印 で示した). 被検児の音声障害については, 検者が障害 を聴覚的に確認し, 音響的分折と聴覚印象で一致して 認められた障害を採用した。

被検児の言語力の評価には, 教研式読書力検查を用 いた。

\section{III. 結 果}

図 1 に, 読書力検査結果を示した. 全症例の偏差值 の平均は, 48.5 とほほ年齢相当の言語発達が認められ た. 聴力別 3 群 : $50 \sim 79 \mathrm{~dB}, 80 \sim 99 \mathrm{~dB}, 100 \mathrm{~dB}$ 以上 の群の偏差值の平均は順に $49.5,48.2,48.8$ であり,

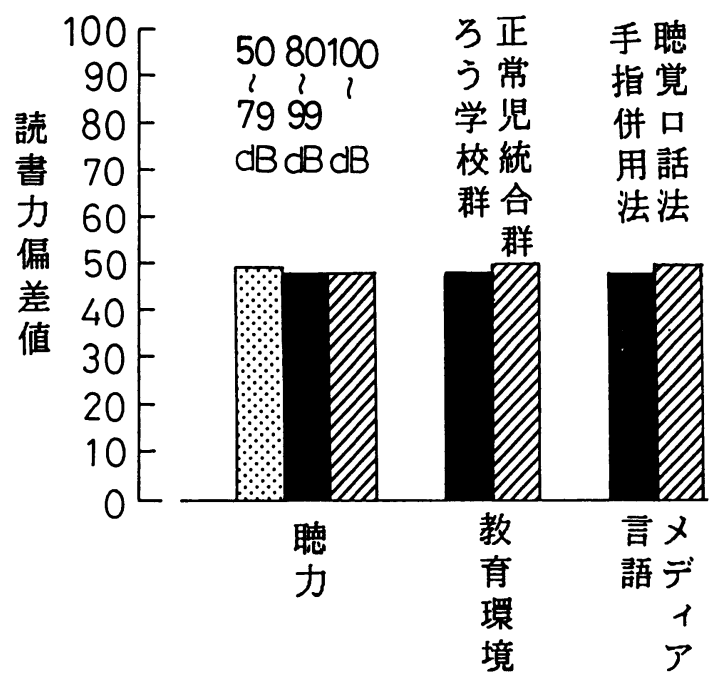

図 1 読書力検査結果. 縦軸に読書力偏差值を示した. 聴力, 教育環境, 言語メディアの要因別の群ご との偏差値の平均を示した。
教育環境別 2 群, ろう学校群, 統合群の平均は順に $47.8,49.7$ であり, 言語メディア別 2 群 : 手指法, 聴 覚口話法の平均は順に $47.7,49.9$ であり偏差值の平均 の差はわずかであった，聴力程度や，各種教育要因の 差によっても言語力については症例間の差がないとい う結果を得た。

次に, 図 $2 \sim 7$ に, 聴覚障害児の音声障害と聴取能 についての結果を示した. 聴力程度と, (a)幼児期の教 育環境，(b)幼児期の言語メディアとの関係を示した。 図 2〜 7 では, 各分析結果について, 聴力程度別 5 群 の被検児の群ごとの平均值を細い線で結んで示し(以 下, 平均聴力別グラフと称す), 教育的要因別の分析結 果を太線のグラフで重ねて示した。

図 2 に, 発話のピッチについての分析結果を示した. 平均聴力別グラフでは聴力 $100 \mathrm{~dB}$ 群のピッチの平均 $(262.5 \mathrm{~Hz})$ は, $70 \mathrm{~dB}$ 群の結果 $(222.6 \mathrm{~Hz})$ より上昇 を認めた。グラフは全般に平坦で, 隣り合う聴力別の
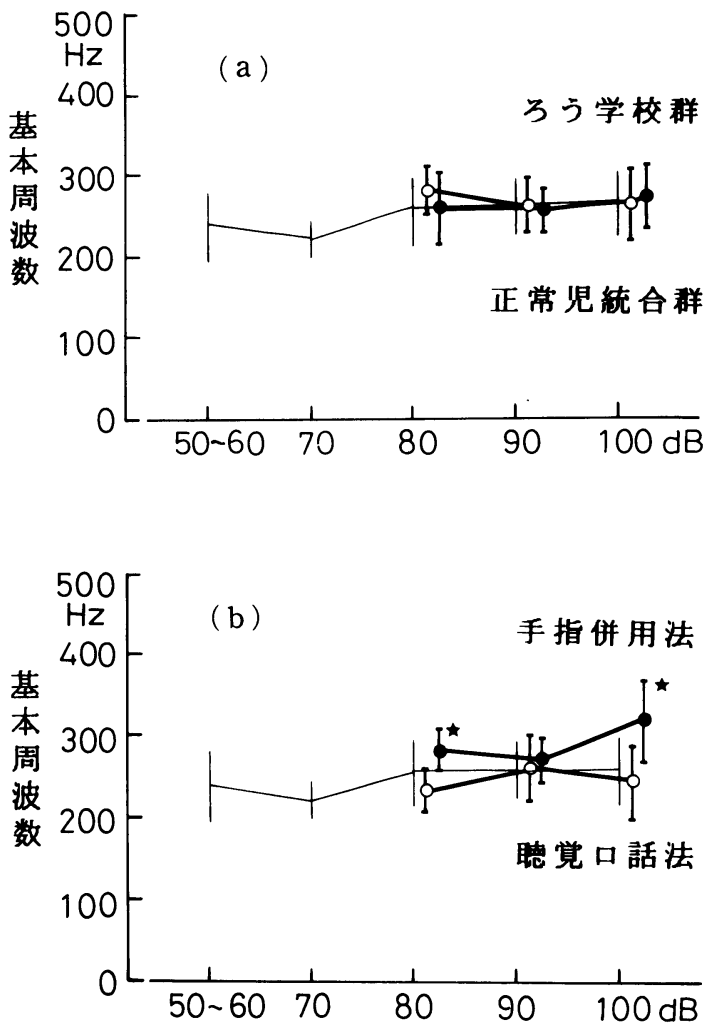

図2 発話のピッチ.上段 (a)に幼児期の教育環境, 下段 (b) に幼児期の言語メディアの要因を検討 して示した. 縌軸に, 被検児の発話の基本周波 数を示し, 図には, 聴力別群ごとの平均值と 1 標準偏差を示した。 
2 群間に発話のピッチの差が少なかった. 図 $2(a) に$, 幼児期の教育環境の影響について示した。発話のピッ チは, 万う学校経験例と正常児統合例との差は少なか つた. 図 2 (b)の言語メディアについては, 手指法を併 用した聴力 $80 \mathrm{~dB}$ 群 $(281.9 \mathrm{~Hz})$ と, 聴力 $100 \mathrm{~dB}$ 群 $(320.3 \mathrm{~Hz})$ の結果は, 聴覚口話法の同程度の聴力レベ ルの症例の結果 $(237.3 \mathrm{~Hz}, 246.7 \mathrm{~Hz})$ と比べてピッ チの上昇を認めた。

図 3 に, 発話の速度についての分析結果を示した。 平均聴力別グラフでは, 難聴が重度になると, 持続時 間が延長し, 発話速度が低下する傾向を認めた。特に, 聴力 $90 \mathrm{~dB}$ 群の持続時間の平均 $(291.6 \mathrm{msec})$ は, 聴 力 $80 \mathrm{~dB}$ 群の結果 $(259.4 \mathrm{msec})$ より延長し, 後者は 聴力 $70 \mathrm{~dB}$ 群の結果 $(165 \mathrm{msec})$ より延長し, 発話速 度の低下を認めた。図 3 (a)に示す幼児期の教育環境に ついては, 聴力 80 90 dB 群の高度難聴例では, ろう 学校例の結果 $(277.8 \sim 308.1 \mathrm{msec})$ は, 正常児統合例 の結果 $(234.1 \sim 248.9 \mathrm{msec})$ より 1 拍の持続時間が延 長していた. 図 3 (b)に示す聴力 $80 \mathrm{~dB}$ 群の手指法併用
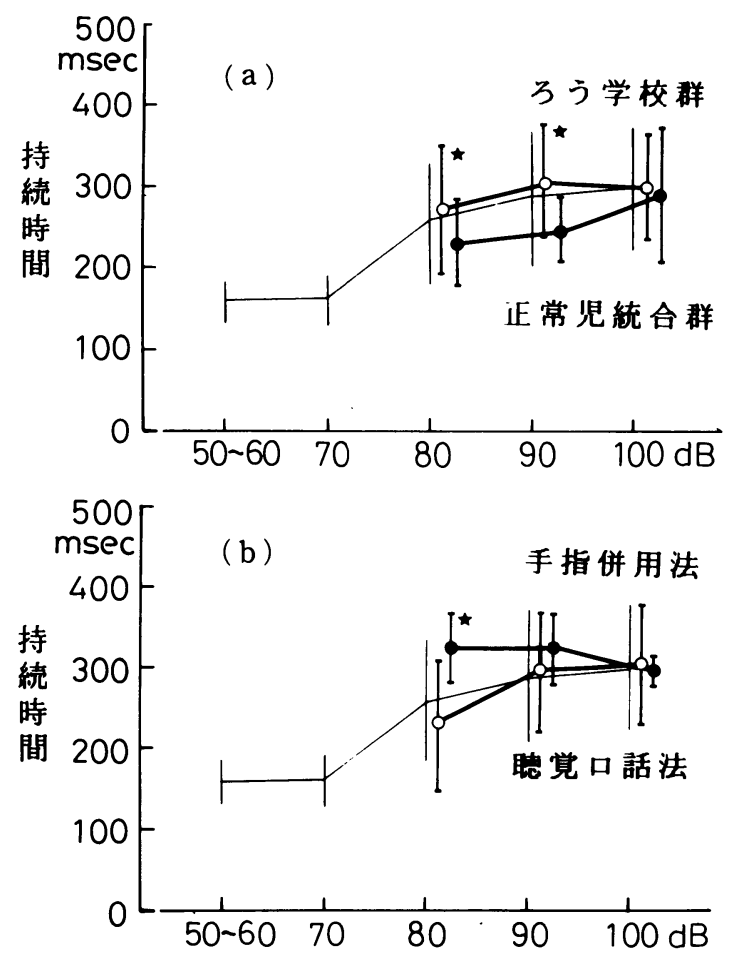

図3 発話の速度. 上段 (a) に幼児期の教育環境, 下 段 (b) に幼児期の言語メディアの要因を検討し て示した. 縦軸に, 自由発話の 1 拍あたりの持 続時間を示し, 図には, 聴力別群ごとの平均值 と 1 標準偏差を示した。
例の結果 $(327.5 \mathrm{msec})$ は, 同程度の聴力の聴覚口話 法例の結果 $(228.5 \mathrm{msec})$ より延長して, 発話速度の 低下を認めた。聴力 $80 \mathrm{~dB}$ 群の手指法併用例の結果 は, $90 \mathrm{~dB}$ 以上の症例の結果 $(327.4 \mathrm{msec})$ と差がなか つた. $100 \mathrm{~dB}$ 以上の症例では, 教育環境と言語メディ ア両者の教育要因による結果の差は認められなかっ た.

図 4 に, 発話の抑揚の分析結果について示した。平 均聴力別グラフでは, 聴力 $80 \mathrm{~dB}$ 群の結果 (43.5\%) は, 聴力 $50 \mathrm{~dB}$ 群の結果 $(48.0 \%)$ より隇少し, 発話 の抑揚が少なくなった. 聴力 $100 \mathrm{~dB}$ 以上の症例では (41.4\%), さらに発話が平坦になる傾向を認めた。図 4 (a)に示す幼児期の教育環境の影響は, 発話の抑揚に ついては認められなかった. 図 4 (b)の言語メディアに ついては, 聴力 $100 \mathrm{~dB}$ 以上の症例において, 手指法併 用例の結果 $(35.3 \%)$ は, 聴覚口話法例の結果 $(43.3$ \%)より発話の抑揚が低下していた。

図 5 に, 音声の強さの変動について示した. 平均聴 力別グラフでは, 聴力 $70 \mathrm{~dB}$ 群の結果 $(21.8 \%)$ は,
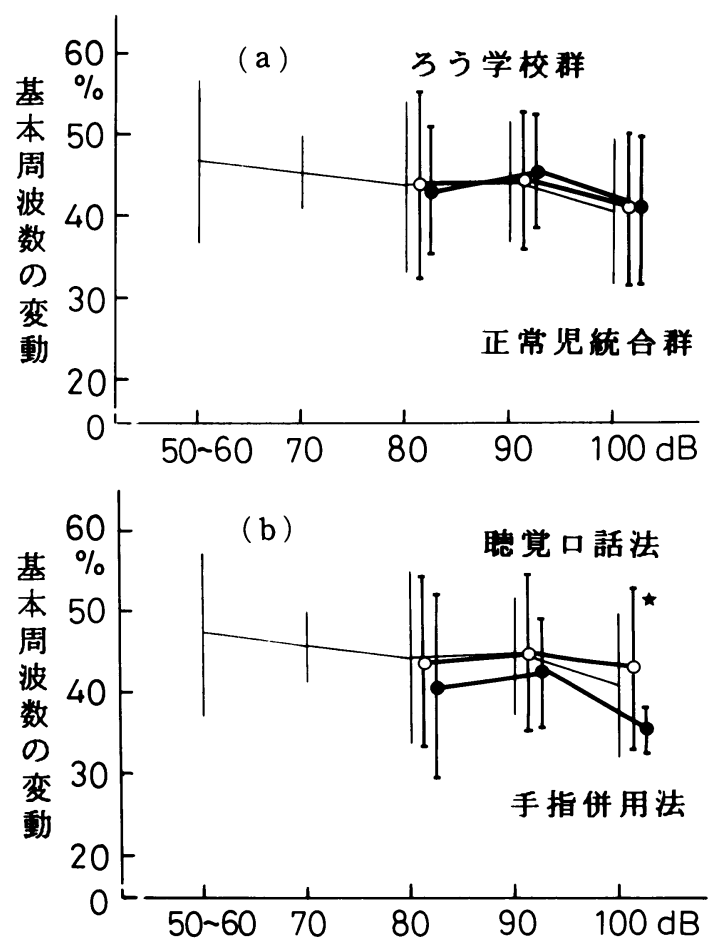

図4 発話の抑揚. 上段 ( a ) に幼児期の教育環境, 下 段 (b) に幼児期の言語メディアの要因を検討し て示した。縦軸に, 症例ごとの基本周波数の 1 標準偏差を示した. 図には聴力別の群内の平均 値と 1 標準偏差を示した. 
聴力 $50 \mathrm{~dB}$ 群の結果（18.6\%）より増大した。聴力 $70 \sim 100 \mathrm{~dB}$ の群間に差が認められず, 聴力 $70 \mathrm{~dB}$ 以上 の症例で音声の強さの変動が影著になったといえる. 図 5 (a)に示す幼児期の教育環境については, 音声の強 さの変動に差が認められなかった. 図 5 (b)に示した言 語メディアについては, 手指法併用例では (22.0〜 24.7 $\%)$, 聴賞口話法例 (17.8〜 19.1\%) と比べて全般的に 音声の強さの変動が顕著であった，以上の結果は, 検 者の聴覚印象によっても確認された。

図 6 に, 発語明瞭度検査結果を示した. 平均聴力別 グラフでは, 聴力 $80 \mathrm{~dB}$ 群 (61.6\%), $90 \mathrm{~dB}$ 群 $(46.8$ $\%), 100 \mathrm{~dB}$ 群 (38.4\%) はそれより軽度の聴力程度 の群の結果と比べて明瞭度は低く, 聴力の影響は顕著 といえよう. 図 6 (a)に示す聴力 $80 \mathrm{~dB}$ から聴力 $100 \mathrm{~dB}$ 以上の正常児統合例 $(70.5 \%, 60.0 \%, 48.2 \%)$ では, ろう学校経験例 $(52.8 \%, 33.6 \%, 28.6 \%)$ と比べて 発話の明瞭度が高かった。正常児と統合した聴力 80 $\mathrm{dB} \sim 100 \mathrm{~dB}$ 群の症例は, 前記の聴力別の結果の $10 \mathrm{~dB}$ 軽度の群の症例と同程度の発話の明瞭性を示した. 図
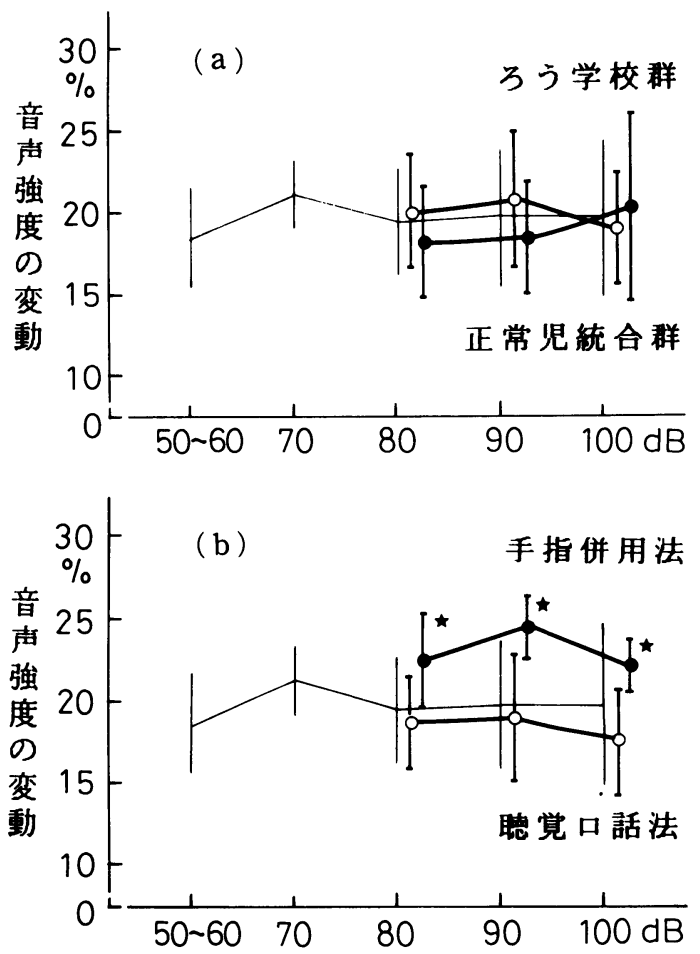

図 5 音声の強さの変動. 上段 (a) に幼児期の教育環 境, 下段 (b)に幼児期の言語メディアの要因を 検討して示した. 縦軸に, 症例ごとの音声の強 さの 1 標準偏差を示した. 図には, 聴力別の群 内の平均值と 1 標準偏差を示した。
6 (b)に示す言語メディアについては, 聴力 $80 \mathrm{~dB}$ 群 (66.0\%) と， $100 \mathrm{~dB}$ 群 (42.3\%) の手指法併用例で は, 同じ聴力群の聴覚口話法例 $(44.0 \%, 23.2 \%)$ に 比べて発話の明瞭性が高かった。

図 7 に, 語音明瞭度検査結果を示した. 平均聴力別 グラフの聴力 $50 \sim 70 \mathrm{~dB}$ 群では， $6 \%$ と群間の差が少 ないが, $80 \mathrm{~dB}$ 群から $100 \mathrm{~dB}$ 群では 10～18\%と難聴 が重度になるにしたがって低下が顕著であった。図 7 (a)の幼児期の教育環境については, 正常児統合群では (43.8\%, 32.0\%, $17.8 \%)$, 万う学校群 $(32.3 \%$, $8.3 \%, 2.4 \%)$ と比べて全般的に語音弁別能が良好で, ろう学校群の約 $10 \mathrm{~dB}$ 軽度の群と同程度の語音弁別 能が得られた. 図 7 (b)の幼児期の言語メディアの差に よる影響は認められなかった。

\section{IV. 考 察}

本研究の目的は, 中・高度聴覚障害児の音声障害に ついて，1）幼児期の言語教育要因（教育環境と, 言 語メディア）相互の影響および，2）指導方法の差異
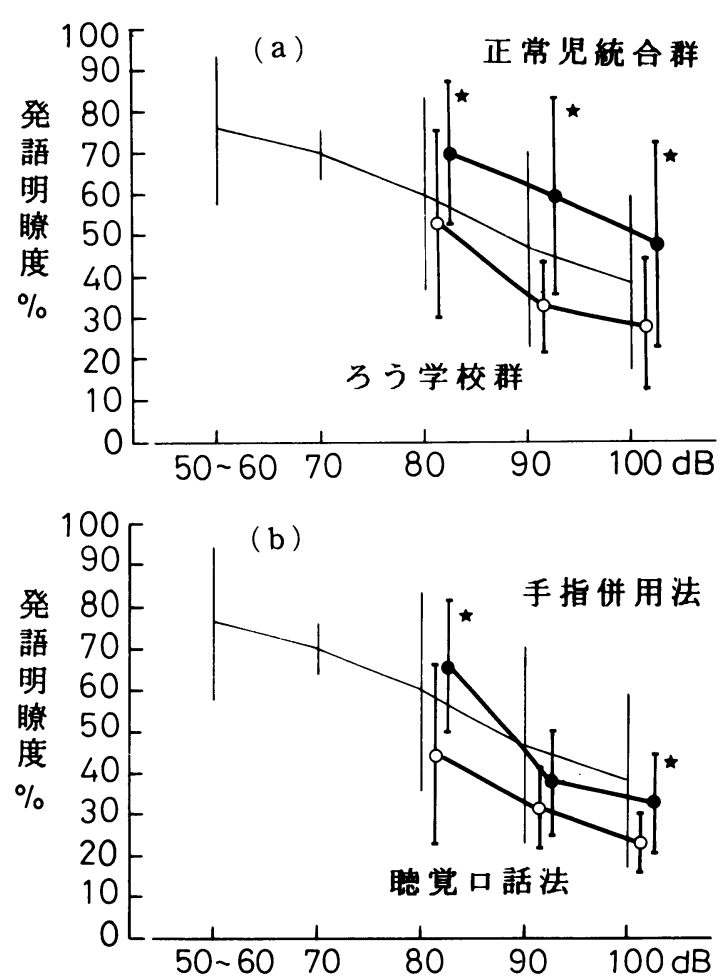

図 6 発語明瞭度検査結果.上段 ( a ) に幼児期の教育 環境，下段 (b)に幼児期の言語メディアの要因 を検討して示した. 図には, 聴力別の群内の平 均値と 1 標準偏差を示した。 

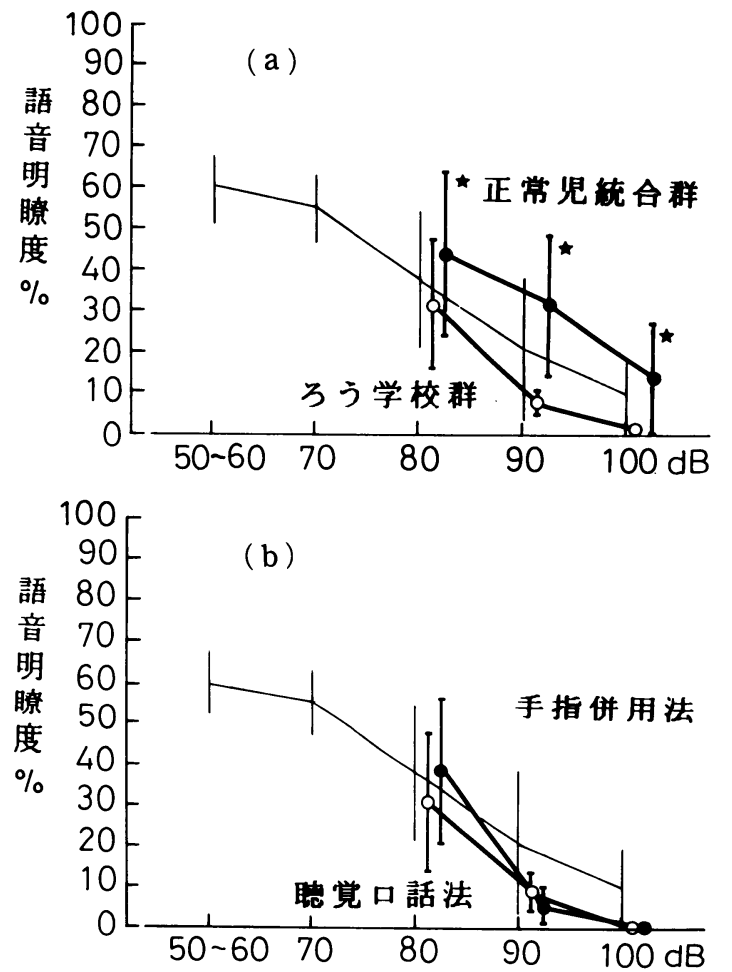

図 7 語音明瞭度検查結果. 上段 ( a ) に幼児期の教育 環境，下段（b)に幼児期の言語メディアの要因 を検討して示した。図には, 聴力別の群内の平 均値と 1 標準偏差を示した。

と, 難聴の程度による影響の差異を明らかにすること にある。

\section{1. 聴覚障害による音声障害の特徵}

聴覚障害児の韻律的障害の特徵としては，1）話声 位の上昇ないし下降，2）抑揚の減少ないし過剩な変 化, 3 ) 発話速度の低下, 4 ) 持続時間の調整の誤り, 5 ) 爆発的な音声の強さの変動が 1942 年に Hugins ${ }^{14)}$ によって指摘されている.

本研究でも，1）～5）の障害の特徵の一部が認め られ, 重篤な障害はわずかな例のみに認められた。今 回の症例には, 話声位の上昇した症例があるものの, うら声を用いていた症例は 112 名中 3 名にすぎなかっ た. 抑揚については, 滅少している例が多く認められ, 過剩な翻転は上記の 3 名のみであった。また, 強さの 変動については, 障害の著しい症例でも $20 \sim 25 \%$ 程度 で不自然さはあっても爆発的な状態のものはなかっ た.この成績は, 難聴を早期発見し, 補聴器を活用し た早期教育の結果の反映といえるであろう.

1980 年に, Subtelny による the National Technical
Institute for the Deaf (NTID) の聴覚障害学生 800 例 の音声障害の特徵を検討した報告 ${ }^{15)}$ があるが, 1 ) 明瞭 性, 2 ) 話声位, 3 ) ピッチ調整, 4 ) 子音産生の速 度，5）呼気の消費調整，6）プロソディ，7）緊張 性の発声，8）気息性の発声，9）鼻腔，口腔共鳴の 障害など，障害の種類については，従来からの報告と かわりがない. 同じく, NTID の聴覚障害学生の音声

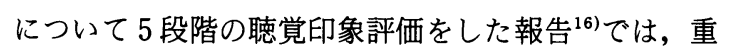
度と最重度に分類される障害はプロソディの障害が $22 \%$, 気息性の音声 $20 \%$, 話声位とピッチ調整の障害 $10 \%$, 過緊張発声 $8 \%$, 鼻腔共鳴過剩 $6 \%$ であり重度 障害の占める割合は減少傾向が指摘された。

\section{2. 音声障害と聴力要因の関係}

本研究では, 難聴が高度になると以下のように音 声・聴取能の障害の程度が重度になり, 障害の種類が 増加することが明らかになった。a）聴力 $70 \sim 79 \mathrm{~dB}$ 群：音声の強さの変化の增大. b) 聴力 $80 \sim 89 \mathrm{~dB}$ 群 : 発話の速度の低下. 抑揚の減少. c) 聴力 $100 \mathrm{~dB}$ 以上 群 : 発話のピッチの上昇. 発話の抑揚が平坦. そして, 発語明瞭度と語音弁別能については, 難聴が高度にな るにしたがい徐々に低下した。

今回は, 教育条件の異なる症例を加え 112 例につい て聴力を検討したが，難聴が高度になったときの障害 の重度化の傾向は, 以前の 36 例について得た結果 ${ }^{13)}$ と 一致していた。障害の種類については, 今回は, 䫓律 的障害についての分析パラメー夕を増やし, 聴力 100 $\mathrm{dB}$ 以上の症例にも言語教育要因の差異の影響を認め た点が以前の結果 ${ }^{10,11)}$ と異なっていた。 今回は, 聴力 $100 \mathrm{~dB}$ 以上群についても, 手指法併用例は聴覚口話法 例より韻律的障害が顕著であり, 聴力 $100 \mathrm{~dB}$ 以上群 の教育方法のあり方についての検討の必要性が示唆さ れた。

聴覚障害児者の音声障害について, 難聴の程度別に 症例を分類して検討した報告は，著者が調べた範囲で は少なく, 聴力と教育要因の影響の比較は不明なまま になっていた，本研究では，中・高度聴覚障害児を聴 力 $10 \mathrm{~dB}$ ステップで 5 群に分け, 音声障害について教 育要因の影響を検討した。 その結果，教育要因の差異 が及ほす影響は，聴力レベルの差異がもたらす影響ほ ど顕著ではなかった，教育条件によって期待できる障 害の改善は, 発話の速度 (図 3 ), 発語明瞭度 (図 6 ) で聴力が $10 \mathrm{~dB}$ 軽い群のそれにほほ相当するという 結果を得たことは臨床評価に重要な知見といえる.

\section{3. 正常児との統合教育の意義}

1987 年の全国調查 ${ }^{17)}$ では，ろう学校幼稚部 83 校 (77.6\%), 難聴児通園施設 18 施設 $(78.3 \%)$, センタ 
一・病院・クリニック 13 カ所から回答を得た。聴覚障 害幼児 2,677 人のうちろう学校に, 1,918 人 (72\%) が在籍し，759人 (28\%) はそれ以外の施設で指導を 受けていた。近年では, 後者に高度難聴例が増える傾 向にあるが, 同調查では, 病院や通園施設では, $80 \mathrm{~dB}$ 未満の症例の割合が多いと報告されている.

本研究では, 正常児との結合保育をした症例におけ る音声の障害は, ろう学校幼稚部を経た症例より軽度 であり, 単音節の聴取能が良好であるという知見をえ た. 加えて, 統合教育は, 聴覚障害児のコミュニケー ションカや社会性の発達, 自己概念の形成などを促す という人格形成の面でも重視される(10)だけに, 幼児期 から正常児の集団と交流の機会を作ることが望ましい と考えられる. 統合教育には, 聴覚障害児を普通幼稚 園, 小学校に在籍させる統合方式や, ろう学校に在籍 させて正常児と交流の機会をもつ方式がある。聴覚障 害児にとって, 母国語の獲得は重要な教育的課題であ り，正常児と統合しながら母国語を獲得させるには， 言語学習の視点を養育に織りこむ家族の一貫した協力 が必要になる.さらに, 聴覚障害児自身が正常児の集 団教育の環境で心理的に安定して学習が続けられる発 達段階にあることが重要になる. 統合の方式や時期に ついては, 個別的な要因を十分検討する必要があろう.

\section{4. 手指法の併用}

聴覚障害児の家族が手話や指文字, キュード・スピ 一チなどの視覚的な手指記号を言語メディアに用いれ ば, 難聴が高度でも日常生活での言語獲得が可能にな り,コミュニケーションが円滑になるということから， 米国では, 約半数の聴覚障害幼児の教育機関で手話な どの手指法を採用している ${ }^{18)}$.わが国では, 約 $30 \%$ の ろう学校で幼児期にキュードスピーチや, 指文字など 音節に対応する視覚的記号を採用し ${ }^{19)}$, 音声言語の習 得と同時に, 手指言語メディアを導入する教育方法の 検討について, 近年, 社会的な要請がある.

本研究では, 幼児期の言語メディアに手指法を併用 した症例の音声障害について, 聴覚口話法を用いた例 と比べて検討し, 聴力 $80 \mathrm{~dB}$ 群において, 発話のピッ チ, 音声の強さの変動, 発話の速さの韻律的障害を認 め, $100 \mathrm{~dB}$ 群において, さらに発話の抑揚の障害が顕 著であった。このような障害が生ずる理由は，1）手 指法併用例では, 音節ごとの手指の動作の速度に発声 を伴うために, 音声のイントネーションや発話速度な どの韻律的な特徵が損なわれる，2）視覚記号に依存 して, 発話の音声勢力が弱まったり, 音声強度の調整 が不足するなど発声の意図がそしくなることが考えら れる. 幼児期早期に手指記号を用いる際には, 音声の
韻律面の学習をどのように補償するか, また, 手指記 号の受信時に視覚系への注目が聴能の発達を抑制ない ようどのように聴覚を活用するか ${ }^{20)}$, 今後検討を要す る問題であるといえる。

また，手指法併用例では，語音の聴取能について聴 覚口話法例と差が少ないにもかかわらず, 発話明瞭度 が高い傾向を認めた。この理由としては, 前者では, 手指記号の使用のつど, 以前学習された構音動作が反 復され, 音韻体系の定着が容易であったことが考えら れる. 同様の傾向は, 書字表記の際に手指法例では, 聴覚口話法例と比べて誤りが少ないという報告 ${ }^{21)} に も$ 示されている。しかし, 本研究で対象としたろう学校 幼稚部での聴覚口話法例の発語明瞭度は, 正常巟統合 例と比べた場合に低值であり, 聴覚活用の不徹底さを 示している可能性も考えられる.

本研究では, 難聴学級に在籍する聴覚障害児を対象 とし, 幼児期の言語メディアが音声障害と語音の聴取 能力に与えた影響が学童期においても認められ，幼児 期の指導方法の選択の重要性が示唆された. 手指言語 メディアの導入には, 手指言語メディアに併用する音 声言語 (恥覚, 読話, 発音, 発語) の活用に十分な配 慮が必要であり, 今後の検討すべき問題といえよう.

\section{V.まとめ}

普通小学校に在籍する中・高度感音性聴覚障害児 112 例を対象として, 自由発話の音声, 発語明瞭度, 語 音明瞭度について検討し, 症例の聴力, 幼児期の教育 環境，言語メディアの要因について分析した。その結 果，1）難聴が高度になると音声障害の程度が重度に なり，障害の種類が増加した。2 ）幼児期にろう学校 を経た症例では，正常児統合例と比べて語音弁別能， 発語明瞭度の障害が顕著であり, 発話速度が低下した。 3 ) 幼児期の言語メディアに手指法を用いた症例では, 聴覚口話法例と比べて韻律的障害（発話のピッチ, 抑 揚, 音声の強さの変動, 発話の速さ)が顕著であった。 発語明瞭度については, 手指法例では聴覚口話法例よ り，障害が軽度であった。4）教育要因の差異が聴覚 障害児の音声障害の程度に及ぼす影響は, 聴力レベル の差異がもたらす影響より顕著でなかった。 5 ) 言語 力については, 聴力の要因や, 各種教育要因による差 を認めなかった。

\section{文献}

1）市島民子：語のプロソディに関する言語環境の影 響-音響分析的検討-聴覚言語障害, $29: 132,1988$. 2）村田孝次：幼児のことばと発音，28-55，1971. 
3）芦川英通, 山田 修, 小寺一興：聴性脳幹反応に よる新生児 - 乳児の他覚的聴力検査, 耳鼻臨床, 75, 7, 1479-1485, 1982.

4）田中美郷：幼児難聴, 医歯薬出版, 1979.

5) Stuckless E. R., Brirch J. W. : The influence of early manual communication on the liguistic development of deaf children, American Annals of the Deaf, $111: 2,452-460,1966$.

6) Vernon M. and Koh S. D. : Effects of oral preschool compared to early manual communication on education and communication in deaf children, American Annals of the Deaf, 116, 569 $-574,1971$.

7) Reich, C., H., et al. : The integration of hearing impaired children in regular classrooms. Amer. Ann. Deaf. 122 : 534-543, 1977.

8）今井秀雄 : 聴覚障害児の言語メディアの検討, 特 別研究報告, 手指法の評価と適応に関する研究, 国立特殊教育総合研究所, 78-83，1983.

9）星名信昭：聴覚障害児の発話資料の分析，聴覚障 害児の言語メディアの検討, 特別研究報告書, 手 指法の評価と適応に関する研究，国立特殊教育総 合研究所, 67-73, 1983.

10）廣田栄子, 芦野聡子, 前田知佳子, 田中美郷：幼 児期の教育環境が聴覚障害児のピッチ, 抑揚, 発 話速度, 発語明瞭度に与える影響の検討, 音声言 語医学, $27: 3,215-222,1986$.

11）廣田栄子, 田中美郷, 前田知佳子, 芦野聡子 : 聴 覚障害児における幼児期の言語メディアと音声言 語発達との関係, 音声言語医学, $29: 3,287-295$, 1988.

12) Nickerson, R., S., : Characteristics of the speech of deaf persons, The Volta Review, $77: 342-362$, 1975.
13）廣田栄子, 工藤多賀, 田中美郷：聴覚障害児にお ける発話のピッチ・速度, 音声強度の検討, 音声 言語医学, $26: 3,199-208,1985$.

14) Hudgins, C., V., et al. : An investigation of the intelligibility of the speech of the deaf. Genet. Psychol. Monogr., 25 : 289-392, 1942.

15) Subtelny, J., et al. : Description and evaluation of an instuructional program to improve speech and voice diagnosis of the hearing impaired. Volta Review, 79 : 85-95, 1980.

16) Subtelny, J. : Assessment of speech with implications for training in childhood, Deafness, : Causation, Assessment, and Management, edited by FH Bess, Grune and Stratton, New York, 191, 1977.

17）今井秀雄, 他: 驡学校幼稚部および難聴児通園施 設の実態調查, 国立特殊教育研究所, 1987.

18) Jordan I. K. : Current communication trends at programs for the deaf, American Annals of the Deaf, $121: 6,527-532,1976$.

19）岩城 謙：聴覚障害児の言語とコミュニケーショ ン, 教育出版, 1986.

20）田中美郷, 廣田栄子：難聴幼児の言語指導法をめ ぐって, 音声言語医学, $29: 3,258-266,1988$.

21）我妻敏博: 聴覚障害児における単語の表記能力 と, 認知能力に関する研究一特別研究報告書, 㰍 児・驡精神薄弱児等の言語習得と多様なコミュニ ケーションの応用に関する研究, 国立特殊教育総 合研究所, 45-50, 1986.

別刷請求先：干 173 東京都板橋区加賀 2-11- 1 帝京大学医学部耳鼻咽喉科学教室 廣田栄子 